UDK: 343.85:343.541-053.2/.6

Pregledni rad

\title{
SITUATIONAL PREVENTION OF CHILD SEXUAL ABUSE
}

\author{
Zoran Pavlovic ${ }^{1}$ \\ University of Business Academy in Novi Sad, Faculty of Law \\ Joris Bijvoets ${ }^{2}$ \\ Justitia Digitalis, Middenbeemster
}

Summary: Situational prevention of child sexual abuse represents a relatively new approach in preventing this kind of victimization of the youngest. Summarizing the etiological knowledge regarding general crime and the knowledge of risk factors of sexual victimization there is a comprehensive approach formed which includes environmental manipulation and strengthening of protective factors within the subject context. Accepting the significance of situational prevention the paper will present the implications of certain phenomenological indicators, the analysis of the principles of situational prevention and the survey of typology of sexual offenders and risk factors of sexual victimization development.

Keywords: Child Abuse, Situational Prevention, Risk Factors, Typology.

\section{Introduction}

Sexual abuse of children represents without doubt an exceptionally significant criminological problem. This is distinctly supported by numerous

1 Zoran Pavlovic, Head of the Department for Criminal Law, e-mail: zoran.pav@hotmail.com 2 Joris Bijvoets, CEO of Justitia Digitalis, The Netherlands 
scientific papers which in the previous decades strongly contributed to understanding of phenomenology, etiology and finally prevention of the subject phenomenon. ${ }^{3},{ }^{4}, 5$ However, observing the said segments, there is an impressions of varying results. Thus, while the question of phenomenology, even etiology of sexual violence against children has been clarified extensively, the effects of preventive science and practical protective programs remain rather disputable. ${ }^{6,78}$

Looking back at the concept of causality of sexual violence a considerable number of authors focused primarily on specific characteristics of the abuser's personality, in other words on the disproportion of capacity in relation to a child. The assumed deficit of social skills, cognitive apparatus, reliving of early traumatic experiences, psychiatric problems are among the particularly noted elements within the etiological concept based on risk factors and needs of abusers. ${ }^{9,10}$

However, the authors such as Finkelhor ${ }^{11}$, presenting the so called Precondition model, introduce situational variables into comprehension of dynamics of sexual violence. Thus the mentioned author predicts that a motivated abuser, in addition to overcoming internal inhibitions, must overcome other corresponding external obstacles. Providing physical closeness, opportunity of situation, in other words absence of supervision by a third person, seem to be the main links in the chain of victimization. ${ }^{12}$

The mentioned environmental concept of analysis of causality is certainly not new in criminological thinking. Early in the $20^{\text {th }}$ century already the contributions of the Chicago school clearly referred to the significance of

3 D. Finkelhor, G. Hotaling, I Lewis, .\& C. Smith (1990). Sexual abuse in a national survey of adult men and women: Prevalence, characteristics, and risk factors. Child abuse \& neglect, 14(1), 19-28.

4 I. Intebi, (2003). Child sexual abuse: Risk factors. Child Abuse Research in South Africa, $4(1), 8-11$.

5 S. Boney-McCoy \& D. Finkelhor (1995). Prior victimization: A risk factor for child sexual abuse and for PTSD-related symptomatology among sexually abused youth. Child abuse \& neglect, 19(12), 1401-1421.

6 N. Petković, \& M. Đorđević, (2011). Prevention of sexual abuse of children.Specijalna edukacija i rehabilitacija, 10(1), 121-138.

7 R. M. Bolen (2003). Child sexual abuse: Prevention or promotion?. Social Work, 48(2), 174-185.

8 Z. Pavlović, Seksualna zloupotreba dece - kriminološki i krivičnopravni aspekti. Novi Sad: Pravni fakultet za privredu i pravosuđe, 2013.

9 Ibidem, p.43.

10 L. Neidigh, \& H Krop, Cognitive distortions among child sexual offenders. Journal of Sex Education and Therapy, 18(3), 208-215, 1992.

11 D. Finkelhor, (1984). Four preconditions-a model. Child sexual abuse: New theory and research, 53-68.

12 N. Petković, J. Dimitrijević, \& M. Đorđević, Seksualna zloupotreba dece: teorijski modeli eksplanacije. Socijalna misao 1, 9-25. 2011. 
immediate environment regarding criminal inclination. Guided by the theory of rational choice, environmental design theory, routine activity theory and theory of lifestyle, ${ }^{13}$ the environmental specificity has been identified as powerful variable in risk assessment and expected benefit. ${ }^{14,15}$

Although juvenile delinquency, violent and property-related crimes as the most frequently considered types within the context of situational prevention cannot be interpreted at the same etiological level as the problem of sexual violence, micro-ecological level of analysis of influence and the principles of situational prevention can clearly be applied within the given framework. ${ }^{16}$

It is exactly to this effect that situational implications of phenomenological characteristics of child sex abuse will be presented further in the text, and then the analysis of principles of situational context and finally the review of typology of sexual offenders within the subject field.

\section{Some Implications of Phenomenological Characteristics of Child Sexual Abuse}

Guided by the statements of Tunnel, the etiological analysis of various offences is based on the assumptions that the elevated degree of irrationality in action goes on the account of significance of situational variables. Consequently, the analysis of sexual violence against children that is seen as a product of irresistible pathologized urge, often predicts the significance of environmental context. ${ }^{17}$

Wortley and Smallbone, ${ }^{18}$ presenting the results of various studies, still refer to another interpreting trajectory. Namely, summing up the phenomenological indicators, the average age when convicted abusers get the first sexual contact with a child is 32.4 years. Similar, although a little bit higher results, are reached by Lung and Huang, ${ }^{19}$ who point out that abusers are between 36.8

13 R. V Clarke,. Situational crime prevention. Crime and Justice, 19(1), 91-150. 1995.

14 N. Milić, (2014). The crime scene in theoretical reflections on crime. Nauka, bezbednost, policija, (1), 141-159.

15 F. P. Williams, \& M. D. McShane, Criminological theory. NY: Prentice Hall, 2004.

16 M Kovačević-Lepojević,. \& V. Žunić-Pavlović, Teorijski i praktični aspekti situacione prevencije. U Žunić-Pavlović, V. \& Kovačević-Lepojević, M. (Ur.), Prevencija i tretman poremećaja ponašanja. Beograd: Fakultet za specijalnu edukaciju i rehabilitiaciju. 91-109, 2010. $17 \mathrm{~K}$. Tunnell. The impulsiveness and routinization of decision-making. In A.R. Piquero and S.G. Tibbetts (eds.), Rational choice and criminal behavior: Recent research and future challenges. NY: Routledge. 2002.

18 R., Wortley \& S. Smallbone, Situational prevention of child sexual abuse. Crime prevention studies (Vol. 19). Monsey, NY: Criminal Justice Press. 2006.

19 F. W. Lung, \& S. F. Huang, Psychosocial characteristics of criminals committing incest and other sex offenses: a survey in a Taiwanese prison. International journal of offender therapy and comparative criminology,48(5), 554-560, 2004. 
and 42.7 years of age. Consequently, the previously mentioned authors find that sexual offenders actually have capacity to postpone gratification and the actual approach to a child for a long period of time. This is ascertained important considering the early developmental hypothesis of pro-paedophile affinity and the significance of opportunistic implications according to which abuse requires a specific situational framework.

Although the public debates often refer to high rate of recidivism of sexual offenders, Greenberg ${ }^{20}$, analysing the efficiency of treatment options established for paedophiles, find that over $89 \%$ of examinees included by the research had only one victim. Somewhat lower results are obtained by Smallbone and Wortley $^{21}$, who at the sample of 182 offenders convicted of sexual offences against children, find that $48.8 \%$ of examinees admitted to have had only one victim. Such indicators can then be reinterpreted within the context of limited situational options and opportunities to commit a crime.

Analysing a wide scope of scientific works which deal with modus operandi of sexual offenders, it is noted that a significant segment of these criminal offenders fantasize about or plan to commit a crime long before the real actualization. Thus there are works in the literature which refer to the existence of specific strategies for direct approach to a child, as well as strategies that provide for the offender to be left alone with an unsupervised child. ${ }^{22}$

However, it is worth mentioning that many clinical and forensic oriented authors find that before committing a specific criminal offence the offenders found themselves in a seemingly favourable situations on several occasions, but they did not use it. Additionally, the evaluation of favourability first refers to isolation, i.e. the absence of supervision of a child. However, when analysing the situational context, we must take into account a somewhat wider perspective. Thus, the research based on auto-reports of offenders suggests that in addition to direct situational framework the commitment depends on the constellation of a larger number of factors which include also the characteristics of a child, direct urging hyperarousal of the offender, as well as the existence of other initiating factors. It is therefore clear that the situational framework does not represent a causal factor per se, but only in synergy with personality characteristics. ${ }^{23}$

20 D. Greenberg, Evaluation of The Western Australian Sex Offender Treatment Unit (1987-1999): A Quantitative Analysis. Sort, 50(100), 500-515, 2002.

21 S. W., Smallbone, \& R. K. Wortley, Child sexual abuse: Offender characteristics and modus operandi (Vol. 193). Australian Institute of Criminology. 2001.

22 B., Leclerc, J., Proulx, \& E Beauregard, Examining the modus operandi of sexual offenders against children and its practical implications.Aggression and violent behavior, 14(1), 5-12, 2009.

23 R., Wortley, \& S. Smallbone, Situational prevention of child sexual abuse. Crime prevention studies (Vol. 19). Monsey, NY: Criminal Justice Press, 2006. 
Although it is rather difficult to limit the sexual offences against children to a corresponding territorial setting, the importance of environmental framework becomes more than obvious by reviewing phenomenological indicators. Namely, following the research of Petković and Pavlovićc ${ }^{24}$, which based on the study of 199 cases of violence against children in Serbia, it can be noted that practically all recorded cases are committed by familiar persons, while predominant offenders are the father, the step father or the mother. These findings which suggest the consistency of high prevalence of interfamilial violence are clearly confirmed by many other studies as well, and they bear clearly strong situational and opportunistic implications. ${ }^{25,26}$

The significance of situational setting is noticeable also in the context of sexual violence committed by women. In the presentation of typology of women abusers those who particularly stand out are heterosexual caregivers, as the category which particularly exploits the advantages of exclusive relationship with children without supervision.

Similar observations are noted by the research of Sullivan and Beech, who conducted research at the sample of 27 priests, 10 teachers and 4 social workers convicted for the said crimes. ${ }^{27}$ Namely, the mentioned study which focused on long-term planning of crime, presented the results according to which $57 \%$ of examinees stated that they chose their profession or line of work exclusively or partially because of the possibility to have easier access to potential victims.

Summing up the above said, the presented segment of phenomenological features clearly indicates the significance of micro-environmental organization as a variable which finds equal significance in the etiology of sexual violence as well as the very psychical structure of the offender. Various indicators thus undoubtedly suggest that violence in the majority of cases happens only after the situational conditions have been fulfilled, regardless of the intensity of sexual urges.

However, it must bear in mind that besides the consciousness of the environmental context of this kind of crimes, creating the effective situational prevention represents rather a complex challenge. This results first of all from the fact that a considerable portion of abusers are the members of close or wider family, who by their position and function should play the role of supervisors. However, as stated by Simon and Zgoba various research suggest that over

24 N. Petković, \& Z. Pavlović, Zlostavljanje i zanemarivanje dece u Srbiji. Novi Sad: In press, 2016.

25 Mažibrada, I. Seksualno zlostavljanje dece i adolescenata. u: Srna, J.(ur.), Od grupe do tima, Beograd: Centar za brak i porodicu, 2002.

26 Burger,., \& K. Reiter, Seksualno zlostavljanje dece i mladeži.Stuttgart, Berlin, 1993.

27 J., Sullivan \&, A. Beech, A comparative study of demographic data relating to intraand extra-familial child sexual abusers and professional perpetrators. Journal of Sexual Aggression, 10(1), 39-50, 2004. 
$40 \%$ of offenders are the acquaintances outside family, which leaves quite a wide manoeuvring space to apply the principles of situational prevention to a considerable portion of potential abuse cases. ${ }^{28}$

\section{Principles of Situational Prevention}

Application of the principles of situational prevention of sexual violence against children has so far been limited in practice. This is why it is difficult to find reliable evaluation studies which tested the effectiveness of this type of intervention. Additionally, some strategies, particularly those suggested by Cornish and Clarke and Wortley seem difficult to apply in relation to the full phenomenological framework of child sexual abuse. ${ }^{29},{ }^{30}$ However, considering the available range of various interventions of this type, phenomenological comprehension of this model has been expanded considerably by the synergetic application of various mechanisms of situational prevention.

Analysing the available literature the said framework of prevention includes four vital principles: increased efforts, increased risks and control of antecedent stimuli. The increased sense of shame and guilt, in other words minorization of the space for rationalization and justification, can be added to these, as a particularly important framework regarding sexual violence. All presented elements, although limited in content, represent a part of a unique strategy and in practice they often imply certain overlapping within practical interventions. ${ }^{31}$

The first segment which implies increased efforts refers to the application of those preventive procedures that would make the commitment of the offence more difficult. This refers both to predatory offenders as well as opportunistic abusers, and within the context of inhibiting or complete determent.

Applicative strategies which may be included in this framework are heterogeneous in content, and they include various segments ranging from legislative to direct security procedures. Thus, for instance, in the USA the laws such as Megan's Law anticipate notifying the members of local community

28 L. M., Simon, \& K Zgoba,. Sex crimes against children: Legislation, prevention and investigation.In Wortley,R. \& Smallbone, S. (Eds.) Situational prevention of child sexual abuse. Crime Prevention Studies, 19, Monsey, NY: Criminal Justice Press.65-101, 2006.

29 Cornish, D. B., \& Clarke, R. V. Opportunities, precipitators and criminal decisions: A reply to Wortley's critique of situational crime prevention.In Smith, M \& Cornish, D. (Eds.) Theory for practice in situational crime prevention. Crime prevention studies, 16, 41-96. 2003.

30 R. A Wortley, classification of techniques for controlling situational precipitators of crime. Security Journal, 14(4), 63-82. 2001.

31 M. Kovačević-Lepojević, \& V Žunić-Pavlović,. Teorijski i praktični aspekti situacione prevencije. U Žunić-Pavlović, V. \& Kovačević-Lepojević, M. (Ur.), Prevencija i tretman poremećaja ponašanja. Beograd: Fakultet za specijalnu edukaciju i rehabilitiaciju. 91-109, 2010. 
of the presence of a convicted sexual offender in their neighbourhood and their identification. Further, the law anticipates limiting territorial distance of residence of the offenders convicted of this type of crime to the places where children usually gather. This refers to schools, kindergartens or other similar institutions, and this provides for spatial distance and reduction of contacts with potential victims. ${ }^{32}$

Similar strategies include also the application of special measures of control of access to schools or childcare centres in terms of identification and registration of visitors. Finally, considering the existence of convicted sexual offenders' data bases in the countries such as the USA, the preventive strategies include mandatory actions by the employers to the employees and volunteers in terms of security background check for all professions related to children. The mentioned strategy can be supplemented by classic forms of situational prevention which include further application of physical barriers, locks and other obstacles which would prevent physical access to children or observing them. ${ }^{33},{ }^{34}$

Although the goal of child preventive programs is to empower capacities of assertiveness and readiness of a child to say no to the abuser or to report violence and although they represent a separate part of the efforts to suppress and prevent this type of crimes, they are presented in the literature as integral segment of situational prevention. However, summary review of the conclusions of many authors regarding this segment gives the impression that they are inconclusive. This primarily refers to the perception of negative effects on children who participate in the preventive curricula, various effectiveness of the learned behaviours of children, the capacity to retain content, disproportion of capacities of children and abusers, the possibility of transfer of knowledge, and unjustified transfer of protective responsibility to the child itself. ${ }^{35}$

In addition to the activities that are aimed to increase efforts required to overcome resistance of a child, a vital part of situational prevention includes the so called controlling tools. The given segment primarily refers to the restriction of availability of pornography and child pornography as elements which are brought into correlation with contact forms of sexual abuse of the children ${ }^{36}$. Preventive actions to that effect include legislative and practical limitations of availability of prohibited materials, and include criminal prosecution of

32 A. J., Petrosino, \& C. Petrosino, The public safety potential of Megan's Law in Massachusetts: An assessment from a sample of criminal sexual psychopaths. Crime \& Delinquency, 45(1), 140-158, 1999.

33 Ibidem p. 99

34 P. D., Kernsmith, S. W., Craun, \& Foster, J. Public attitudes toward sexual offenders and sex offender registration. Journal of child sexual abuse,18(3), 290-301, 2009.

35 Wortley, R., \& Smallbone, S. (2006). Situational prevention of child sexual abuse. Crime prevention studies (Vol. 19). Monsey, NY: Criminal Justice Press.

36 Z., Pavlović, N. Petković, \& J. Matijašević, Dečja pornografija. Zbornik radova Pravnog fakulteta u Splitu 11(2), 45-61, 2014. 
individuals who produce, possess and distribute child pornography, then the control of servers and the contents of sites as well as the removal of the said sources from the Internet.

Similar framework of control tools includes legally provided measures in the USA by which the individuals convicted of these crimes are prohibited to have computers during or after parole, and they are required to meet specific requirements of identification when accessing the Internet and social networks. Namely, accepting the cyber space as a part of reality in which a large number of predators resort to grooming, i.e. finding and recruiting of victims, the application of the said measures can be comprehended within the context of situational prevention. ${ }^{37}$

The second segment of efforts seems to be the most potent in the preventive context. This refers to the increased risk of detection of an offender, i.e. discovering the offence committed. Namely, guided by the assumptions of the routine activity theory and the theory of rational choice the lack of adequate supervision, i.e. the increase of level of supervision can act as attracting or deterring factor in terms of criminal decision making. ${ }^{38}, 39$

The stated level of supervision can imply various manifesting forms, such as prolonged care, formal supervision, removal of physical barriers and enabling natural monitoring and observation, application of contemporary technical supervision devices, as well as training of security managers at the locations noted as the locations of special risks.

By reviewing the phenomenological indicators, the violence by a person known to a child is statistically the most frequent. To that effect the parents, although they bear a considerable risk of child victimization, represent the greatest preventive potential. Situational prevention to that effect means integrating efforts of preventive programs directed at parents in terms of parent or caretaker training to recognize risky situations and the first signs of victimization. Contemporary preventive programs, in addition to referring to danger strangers, integrate also educational contents which raise consciousness of the violence inside primary family. ${ }^{40}$

37 Z Pavlović,. \& N. Petković, Prevencija seksualnih delikata na štetu maloletnih lica u novom krivičnom zakonodavstvu. U ur (Kron, L. \& Jugović, A.)Kriminal, državna reakcija i harmonizacija sa evropskim standardima. Beograd: Institut za kriminološka i sociološka istraživanja. 385-403, 2013.

38 D. B., Cornish, \& R. V. Clarke, Opportunities, precipitators and criminal decisions: A reply to Wortley's critique of situational crime prevention.In Smith, M \& Cornish, D. (Eds.) Theory for practice in situational crime prevention. Crime prevention studies, 16, 41-96, 2003.

39 Miró, F. (2014). Routine Activity Theory. The Encyclopedia of Theoretical Criminology. New York: Springer

40 N. Petković, \& Z., Pavlović, Zlostavljanje i zanemarivanje dece u Srbiji. Novi Sad: In press, 2016. 
The second level of preventive efforts refers to the strategies of formal supervision, which again provide for the development of corresponding protocols of supervising the relationship of the employees or volunteers with children. This most frequently refers to organization of work which forbids the employees to be left alone in a room with a child but requests a minimum of two persons, regardless of whether they are teachers, caretakers or they are in some other profession.

The examples from the national criminal law practice suggest there are other needs to implement preventive strategies of the stated level. Thus, for instance, there are cases recorded of abuse of the pupils in schools which were made in locked classrooms. The accessibility to children and preventing physical control and supervision led to consequential architectural modifications, to redesigning of classrooms which have constant possibility of direct visual surveillance.

Similar deterring mechanisms can be provided by video surveillance. In that way the increased risk of discovering and permanent video storage of the relationship with and treatment accorded to a child considerably narrows the space for prohibited physical contact. The application of corresponding contemporary technologies can thus be publicly marked, as a warning, or can be hidden, which in certain cases provides for vital evidence of child maltreatment.

Following the results of research by Smallbone and Wortley, the review of locations where abusers find their victims supports the requirements of architectural reorganization of other locations besides schools. The mentioned research thus suggests that the access to a victim in $13.2 \%$ cases is made in public toilettes, $11.8 \%$ in shopping malls, $10.5 \%$ at swimming pools, $10.5 \%$ in parks, and $10.5 \%$ in churches ${ }^{41}$ Clearly, this implies specific requirements of lighting, video surveillance, positioning at crowded places, avoiding hidden entrances and rooms, but also the training of security officers. Therefore, a segment of the curriculum of security training of persons working in shopping mall security may, for instance include also the analysis of modus operandi of sexual offenders so that they could recognize suspicious and risky behaviour.

Finally, this segment of situational prevention will include the mechanisms of formal control, which imply the actions of competent bodies such as police or public prosecutor's office. This may refer to monitoring of movements and behaviour of persons who were imposed certain legally prescribed measures of electronic surveillance, which again provides for constant monitoring of high risk individuals and consequently deterrence of offenders. ${ }^{42}$ The same framework of

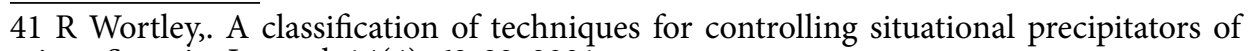
crime. Security Journal, 14(4), 63-82, 2001.

42 N. Mrvić-Petrović, Effectiveness of electronic monitoring applied as integral part of alternative criminal sanctions or measures. Nauka, bezbednost, policija, 20(2), 97-105, 2015. 
formal control includes earlier mentioned monitoring of the Internet activities in terms of identifying IP address and visited web sites, control of transactions and access to incriminated web pages, or finding the persons who abuse materials which are the result of sexual exploitation of children. ${ }^{43}$

Control of antecedent stressors or initiating factors represents the next segment of preventive strategy. The efforts contained in the given context are included by both general activities in terms of mental health maintenance and the specific procedures regarding prevention of relapse. ${ }^{44}{ }^{45}$

Analysing the available literature in both Europe and worldwide, the projects are carried out intended for individuals who recognize inadaptability and danger of their own sexual urges. The program "Stop it now" is certainly a particularly representative example in this context, which provides for the existence of anonymous phone line to which pro-paedophile oriented persons can ask for help. ${ }^{46}$

Namely, the presented program, as well as other program options within the context of situational prevention of reduction of stressors, includes learning and recognizing all those situations which may be sexually provocative and motivating the persons to avoid them. For example, maintaining child's hygiene and bathing it can be seen as potentially provoking situations, which sexually distorted individuals should certainly avoid. Similar example is presented by Finkelhor, who suggests that sexual violence among siblings more often happens if they share a room. ${ }^{47}$ Finally, observed in a wider situational framework, Smallbone et al. suggest that there is the risk related to isolated communities and the effects of social isolation. Namely, observed at the level of mesosystem, and within the context of ecological systems theory, rural communities that have joint sleeping quarters without availability of social services and other forms of supervision may bear elevated level of risk for the appearance of sexual abuse of children. ${ }^{48}$

The last principle included in the concept of situational prevention refers to earlier mentioned reduction of rationalizations and justifications, which

43 B. H., Schell, M. V., Martin, P. C., Hung, \& L. Rueda, Cyber child pornography: A review paper of the social and legal issues and remedies-and a proposed technological solution. Aggression and violent behavior,12(1), 45-63, 2007.

44 R. K., Hanson, \& M. T. Bussiere, Predicting relapse: a meta-analysis of sexual offender recidivism studies. Journal of consulting and clinical psychology, 66(2), 348-356, 1998.

45 W. L Marshall,., Y. M., Fernandez, S. M Hudson,.., \& T Ward,. (Eds.), Sourcebook of treatment programs for sexual offenders. Springer Science \& Business Media, 2013.

46 Z Pavlović,. Seksualna zloupotreba dece - kriminološki i krivičnopravni aspekti. Novi Sad: Pravni fakultet za privredu i pravosuđe, 2013.

47 D. Finkelhor,. Four preconditions-a model. Child sexual abuse: New theory and research, 53-68, 1984.

48 S. W., Smallbone, R. K., Wortley, \& K Lancefield,. Sexual offending by Aboriginal men in Queensland. Brisbane: Queensland Department of Corrective Services, 1999. 
integrates a wide scope of activities included by various preventive actions. Most often this refers to prescribing rather clear legal rules, as well as the rules of behaviour within a certain setting. Public promotion of these rules and introducing them to children, parents and other individuals who are important within the given setting reduces the possibility of excuses such as "I haven't done anything which is not done by other people". Also, by implementing educational programs and providing various printed, video, and TV contents that show the consequences of sexual abuse provides for creation of specific culture of space which neutralizes the excuses which present the given form of violence as education, a child's wish or ultimately the behaviour which does not bear the consequences.

Special framework of strategy of this context refers to the development of specific culture in childcare institutions, whether for the children of general population or particularly the children with special needs. Namely Wortley and Smallbone note the appearance of dehumanization of children, where in totalitarian institutions the employed professionals may revert to violence with rationalization that the victims want or deserve such treatment, that "they are all the same", or that the children do not understand the nature of sexual behaviour and therefore do not suffer any damage. The reduction of such attitudes may be provided by public and clear presentation of rules of behaviour, making the responsibilities precise, creating the space to report victimization, establishing of appropriate supervisory bodies and personalization of children, i.e. potential victims. ${ }^{49}$

Looking back further at the contributions within the context of principles of situational prevention, it is worth mentioning the efforts directed at the reduction of level of expected prize. Namely, following the work by Lamtcik and Glaser the said concept can be understood both in the context of primary and secondary and particularly tertiary prevention..$^{50}$ In other words, it can further be understood as a specific form of imaginative aversion therapy where the motivated offenders are pointed to the personal consequences of committing a crime..$^{51}$ Program contents which refer to certainty of criminal prosecution, bad living conditions in prison, consequential social stigma, isolation, present some of the elements contained in the programs of relapse prevention which incorporate the principles of the stated situational framework.

49 R., Wortley, \& S. Smallbone, Situational prevention of child sexual abuse. Crime prevention studies (Vol. 19). Monsey, NY: Criminal Justice Press, 2006.

50 F., Lambrick, \& W. Glaser, Situational Prevention and Child Sex Offenders with an Intellectual Disability. In Wortley, R. \& Smallbone, S.(Eds.) Situational Prevention of Child Sexual Abuse, Crime prevention studies (Vol. 19). Monsey, NY: Criminal Justice Press.197-223, 2006.

51 Z.Pavlović, Seksualna zloupotreba dece - kriminološki i krivičnopravni aspekti. Novi Sad: Pravni fakultet za privredu i pravosuđe., 2013. 


\section{Typology of Offenders and Risk Factors}

The problem of conceiving a comprehensive practical model of situational prevention has been determined primarily by heterogeneity of approach of sexually violent individuals, i.e. varieties of modus operandi. ${ }^{52}$ This is observed in relation to the presented typology of offenders by Cornish and Clarke, who differentiate among three types of abusers. ${ }^{53}$

Namely, the first category in the typology of the previously mentioned authors includes stereotypical predatory abusers. These are most often the persons who commit sexual violence over a long period of time with multiple victims. Wortley and Smallbone suggest that in the given group a quarter of individuals are the persons who can be identified as persistent sexual offenders, while a considerable share includes the individuals who have prior convictions for non-sexual crimes. ${ }^{54}$ Regarding the selection of victims, this type of offenders most frequently chooses particularly vulnerable children with minimum risk of discovering and consequential legal prosecution.

The second type of offenders are the so called opportunists, i.e. the abusers guided by the same motivation as predatory type, but under higher intensity of social and personal inhibitions. Only under the influence of situational factors the stated constrictions can ease, which leads to sexual approach to children. Wortley and Smallbone mention that approximately a half of the given group is criminally convicted for the first time for a sexual offence committed against a child. Furthermore, regarding the frequency of violence, this group is of considerably lower frequency, while the selection of the victim is made in the context of direct convenience of the access. ${ }^{55}$

In comparison with the first type that is prone to accessing the children of the earliest ages and outside family, the opportunist type more often chooses older female children within the family. Thus while for the predatory type the sexual violence against children has the character of exclusivity and permanence, for the opportunists it would be appropriate to say that they commit violence because they can. Sexual urge to this effect is not of exclusive paedophile type.

52 K. L., Kaufman, Hilliker, D. R., \& E. L. Daleiden, Subgroup differences in the modus operandi of adolescent sexual offenders. Child Maltreatment, 1(1), 17-24, 1996.

53D. B., Cornish, \& R. V. Clarke, Opportunities, precipitators and criminal decisions: A reply to Wortley's critique of situational crime prevention.In Smith, M \& Cornish, D. (Eds.) Theory for practice in situational crime prevention. Crime prevention studies, 16, 41-96, 2003.

54 R., Wortley, \& S. Smallbone, (2006). Situational prevention of child sexual abuse. Crime prevention studies (Vol. 19). Monsey, NY: Criminal Justice Press, 2006.

55 Ibidem,p. 124 
The third type in the classification of Cornish and Clarke is represented by provoked or situational offenders, and as a group characterized by reactive committing of a crime in relation to a specific set of situational, wider social and inter-psychic variables. ${ }^{56}$ Actually, these are generally non-criminal individuals, a considerable portion of whom have not had prior conflicts with the law. Regarding the selection of victims, they usually choose older female children, while regarding frequency they are limited to one child. The nature of sexual urge of situational offenders does not show a pattern of paedophile fixation. In other words, the commitment of a crime does not imply previous planning and instinctive focus, but is the result of decompensation and break down of regulatory mechanisms due to synergic action of various stressors.

Going back to the concept of situational prevention, the environmental variables will have various effects on the mentioned types of offenders. The environmental factors will then represent a challenge for predatory type of offenders, who manipulated the environment with motivation and with behaviour directed at a specific goal. The opportunist type will find the environmental characteristics attractive, i.e. they will evaluate risks and possible benefits, and will commit a crime exploiting the existing environmental setting. Finally, the reactive type will find the environmental characteristics as precipitating factors, which act in either initiating or decompensating manner.

Accepting the mentioned variety of approach in committing sexual offences, the conceiving of effective situational prevention must include the analysis of wide ecological framework. Thus when we talk about socioeconomic structure, special attention should be paid of routine activities and activities included by a lifestyle.

Kaufman et al. underline the risks related to the fact if a child walks to and from the school, if a child uses public transport, or if it takes part in free unsupervised activities after school. Namely, the risk of victimization to this effect is possible to reduce through organization which ensures that children walk from home to school in a group or a shared responsibility of the parents who would on a regular basis supervise children during this path. Also, in order to avoid unsupervised activities of children, conceiving and organizing post-school activities will also have considerable protective potential. The said activities are particularly important if the insight into the register of convicted sexual offenders shows that they live in the territory which is adjacent to the area where children move and gather. ${ }^{57}$

56 D. B., Cornish, \& R. V. Clarke, Opportunities, precipitators and criminal decisions: A reply to Wortley's critique of situational crime prevention.In Smith, M \& Cornish, D. (Eds.) Theory for practice in situational crime prevention. Crime prevention studies, 16, 41-96, 2003.

57 K. Kaufman, \& M. Mosher, An empirically based situational prevention model for child sexual abuse. In. Wortley, R. \& Smallbone, S.(Eds.) Situational Prevention of Child Sexual 
Furthermore, as risk factors there appear family structure, weakly defined family rules, frequent household visitations by acquaintances, limited possibilities of supervision by adults, the requirements in terms of time the parents spend at work, noticeable need to hire caretaker or other individuals to watch a child, the lack of connections in the local community, as well as limited possibilities of supervision by neighbours.

Namely, looking back at some of the mentioned elements, the situational prevention will imply formulation of clear rules of child's behaviour when the parents are not at home. This will refer to limitation of contacts and freedom of access of other adults to a child when the parents are not at home, as well as limitations in terms of freedom to leave home. The prohibition to unlock the door or limiting the space to play which is not outside home are some of the most important examples of this context.

Guided by the examples from practice, which refer to violence against children committed by teachers, educators or trainers, what can be added to this framework of analysis is the participation in various youth and children organizations, as well as the existence of the activities which include severalday trips and absence from home..$^{58}$ Also, as a risk factor there may appear the supervision and taking care of the child by an elder sibling.

The repertoire of measures that can be realized within the given framework includes primarily the implementation of adequate screening by the organizations who hire professionals, in order to limit the access of prior convicts to children. Also, it is necessary to realize the appropriate contents of education that would empower child's capacities, but also make precise the responsibility, roles and consequences of various behaviours.

The second segment of analysis will cover the features of physical environment. Various types of dwelling, the presence of members of wider family in a household and the lack of privacy at home particularly stand out. The same level of analysis will include the lack of clearly enclosed space intended for children playing, migration frequency of the area and the accessibility of persons outside the local community, or the areas characterised by high crime rate and unorganized activities of children after school in the street. Finally, following the elaboration of preventive models of Clarke, the presence of abandoned buildings in a certain area related to children may appear as environmental factor. ${ }^{59}$ Clearly the absence of supervision and isolation offered by such locations may be favourable factors for commitment of sexually violent behaviour, especially of predatory type.

Abuse, Crime prevention studies (Vol. 19). Monsey, NY: Criminal Justice Press.101-145. 2006. 58 Boyle, P. (1994). Scout's honor: Sexual abuse in America's most trusted institution. NY: Prima Pub.

59 R. V. Clarke, Situational crime prevention. Crime and Justice, 19(1), 91-150, 1995. 
It is in this sense actually that the activities otherwise directed at strengthening the general security of the local community would also have influence on the prevention of sexual violence. Identification of risky locations, organization of security patrols consisting of the members of the local community, video surveillance and enclosing of public spaces, referring the children farther from the secluded isolated places will also make strong preventive potential.

The opportunity of situation for committing a crime will include naturally a complex interaction with a number of risk factors at the level of both child and the family. ${ }^{60}$ This refers primarily to the children with a single parent, the children from dysfunctional and disorganized families and socially isolated children. Also, a risk factor may be cognitive disability, child neglecting, particularly of the children from unwanted pregnancies.

Specific situational setting can be mediated by many other factors. In literature the facilitating variables include the availability of weapons, pornography or violence (in family). Wortley and Smallbone, in addition to the previously mentioned, also note the availability of alcohol as a particularly powerful risk factor. ${ }^{61}$ Namely, the said authors, analysing the sexual violence in Aborigine communities, find that in over $80 \%$ cases the child victimization was accompanied by alcohol intoxication of the offenders. Situational concept of prevention to that effect provides for limitation of availability of alcohol, rehab programs, even establishing the communities in which alcohol is forbidden.

Finally, observing in macro-ecological level, the situational prevention would include other factors such as effectiveness of social control mechanisms, existence and quality of supervision of convicted sexual offenders, available programs intended for both convicted and non-delinquent parents, socioeconomic development, presence of corruption in social and police services, anomic quality of a society and similar.

\section{Conclusion}

The concept of situational prevention of sexual abuse of children has clear theoretical confirmation. However, in numerous segments this model actually represents only another perspective of interpreting the factors that have been established for decades in the field of prevention of this kind of violence. It is

60 D., Finkelhor, G., Hotaling, I., Lewis, \& , C. Smith1990. Sexual abuse in a national survey of adult men and women: Prevalence, characteristics, and risk factors. Child abuse \& neglect, 14(1), 19-28, 1990.

61 R., Wortley, \& S. Smallbone, (Situational prevention of child sexual abuse. Crime prevention studies (Vol. 19). Monsey, NY: Criminal Justice Press. 2006. 
therefore justified to ask a question if the situational prevention really brings something new in this field of science.

Summing up the previously elaborated segments, there is an impression that although the subject concept does not reveal any special novelties within the context of sexual violence, it really contributes to the comprehensiveness and rounding up of preventive efforts. Thus, the circle of activities which include program contents directed at children, parents and offenders finally gets a perspective which excludes all those environmental variables which precipitate or facilitate victimization.

Naturally, it must bear in mind that the model of situational prevention carries certain burden as well. Namely, organizing the said type of activities can often grow into paranoia of a kind. If every involvement in the activities of children's organization, every field trip or contact with a neighbour is seen as potentially dangerous, there is a question of disturbance of a healthy developmental process. Prevention of sexual abuse of children to that effect bears a particularly heavy burden of balancing between the stated paranoid level of perception and regular vigilance of parents and sensitivity to possible signs and risks of violence. Only by establishing a given level of balance it is possible to achieve preventive, protective, but also developmental goals directed at children.

\section{References}

1. Bolen, R. M. (2003). Child sexual abuse: Prevention or promotion?. Social Work, 48(2), 174-185.

2. Boney-McCoy, S., \& Finkelhor, D. (1995). Prior victimization: A risk factor for child sexual abuse and for PTSD-related symptomatology among sexually abused youth. Child abuse \& neglect, 19(12), 1401-1421.

3. .Boyle, P. (1994). Scout's honor: Sexual abuse in America's most trusted institution. NY: Prima Pub..

4. Burger, E., \& Reiter, K. (1993). Seksualno zlostavljanje dece i mladeži. Stuttgart, Berlin.

5. Clarke, R. V. (1995). Situational crime prevention. Crime and Justice, 19(1), 91-150.

6. Cornish, D. B., \& Clarke, R. V. (2003). Opportunities, precipitators and criminal decisions: A reply to Wortley's critique of situational crime prevention.In Smith, M \& Cornish, D. (Eds.) Theory for practice in situational crime prevention. Crime prevention studies, 16, 41-96.

7. Cornish, D. B., \& Clarke, R. V. (Eds.). (2014). The reasoning criminal: Rational choice perspectives on offending. London: Transaction Publishers. 
8. Finkelhor, D. (1984). Four preconditions-a model. Child sexual abuse: New theory and research, 53-68.

9. Finkelhor, D., Hotaling, G., Lewis, I., \& Smith, C. (1990). Sexual abuse in a national survey of adult men and women: Prevalence, characteristics, and risk factors. Child abuse \& neglect, 14(1), 19-28.

10. Greenberg, D. (2002). Evaluation of The Western Australian Sex Offender Treatment Unit (1987-1999): A Quantitative Analysis. Sort, 50(100), 500-515.

11. Hanson, R. K., \& Bussiere, M. T. (1998). Predicting relapse: a meta-analysis of sexual offender recidivism studies. Journal of consulting and clinical psychology, 66(2), 348.

12. Intebi, I. (2003). Child sexual abuse: Risk factors. Child Abuse Research in South Africa, 4(1), 8-11.

13. Kaufman, K. L., Hilliker, D. R., \& Daleiden, E. L. (1996). Subgroup differences in the modus operandi of adolescent sexual offenders. Child Maltreatment, 1(1), 17-24.

14. Kaufman, K. \& Mosher, M. (2006). An empirically based situational prevention model for child sexual abuse. In. Wortley, R. \& Smallbone, S.(Eds.) Situational Prevention of Child Sexual Abuse, Crime prevention studies (Vol. 19). Monsey, NY: Criminal Justice Press.101-145.

15. Kernsmith, P. D., Craun, S. W., \& Foster, J. (2009). Public attitudes toward sexual offenders and sex offender registration. Journal of child sexual abuse, 18(3), 290-301.

16. Kovačević-Lepojević, M. \& Žunić-Pavlović, V. (2010). Teorijski i praktični aspekti situacione prevencije. U Žunić-Pavlović, V. \& Kovačević-Lepojević, M. (Ur.), Prevencija i tretman poremećaja ponašanja. Beograd: Fakultet za specijalnu edukaciju i rehabilitiaciju. 91-109.

17. Lambrick, F., \& Glaser, W. (2006). Situational Prevention and Child Sex Offenders with an Intellectual Disability. In Wortley, R. \& Smallbone, S.(Eds.) Situational Prevention of Child Sexual Abuse, Crime prevention studies (Vol. 19). Monsey, NY: Criminal Justice Press.197-223.

18. Leclerc, B., Proulx, J., \& Beauregard, E. (2009). Examining the modus operandi of sexual offenders against children and its practical implications. Aggression and violent behavior, 14(1), 5-12.

19. Lung, F. W., \& Huang, S. F. (2004). Psychosocial characteristics of criminals committing incest and other sex offenses: a survey in a Taiwanese prison. International journal of offender therapy and comparative criminology,48(5), 554-560.

20. Marshall, W. L., Fernandez, Y. M., Hudson, S. M., \& Ward, T. (Eds.). (2013). Sourcebook of treatment programs for sexual offenders. Springer Science \& Business Media. 
21. Mažibrada, I. (2002). Seksualno zlostavljanje dece i adolescenata. u: Srna, J.(ur.), Od grupe do tima, Beograd: Centar za brak i porodicu.

22. Milić, N. (2014). The crime scene in theoretical reflections on crime. Nauka, bezbednost, policija, (1), 141-159.

23. Miró, F. (2014). Routine Activity Theory. The Encyclopedia of Theoretical Criminology.New York: Springer

24. Mrvić-Petrović, N. (2015). Effectiveness of electronic monitoring applied as integral part of alternative criminal sanctions or measures. Nauka, bezbednost, policija, 20(2), 97-105.

25. Neidigh, L., \& Krop, H. (1992). Cognitive distortions among child sexual offenders. Journal of Sex Education and Therapy, 18(3), 208-215.

26. Pavlović, Z. \& Petković, N. (2013). Prevencija seksualnih delikata na štetu maloletnih lica u novom krivičnom zakonodavstvu. U ur (Kron, L. \& Jugović, A.)Kriminal, državna reakcija i harmonizacija sa evropskim standardima. Beograd: Institut za kriminološka i sociološka istraživanja. 385-403

27. Pavlović, Z. (2013). Seksualna zloupotreba dece - kriminološki i krivičnopravni aspekti. Novi Sad: Pravni fakultet za privredu i pravosuđe.

28. Pavlović, Z., Petković, N. \& Matijašević, J. (2014). Dečja pornografija. Zbornik radova Pravnog fakulteta u Splitu 11(2), 45-61

29. Petković, N. \& Pavlović, Z. (2016). Zlostavljanje i zanemarivanje dece u Srbiji. Novi Sad: In press

30. Petković, N., \& Đorđević, M. (2011). Prevention of sexual abuse of children. Specijalna edukacija i rehabilitacija, 10(1), 121-138.

31. Petković, N., Dimitrijević, J. \& Đorđević, M. (2011). Seksualna zloupotreba dece: teorijski modeli eksplanacije. Socijalna misao 1, 9-25

32. Petrosino, A. J., \& Petrosino, C. (1999). The public safety potential of Megan's Law in Massachusetts: An assessment from a sample of criminal sexual psychopaths. Crime \& Delinquency, 45(1), 140-158.

33. Schell, B. H., Martin, M. V., Hung, P. C., \& Rueda, L. (2007). Cyber child pornography: A review paper of the social and legal issues and remedies-and a proposed technological solution. Aggression and violent behavior, 12(1), 45-63.

34. Simon, L. M., \& Zgoba, K. (2006). Sex crimes against children: Legislation, prevention and investigation.In Wortley,R. \& Smallbone, S. (Eds.) Situational prevention of child sexual abuse. Crime Prevention Studies, 19, Monsey, NY: Criminal Justice Press.65-101.

35. Smallbone, S. W., Wortley, R. K., \& Lancefield, K. (1999). Sexual offending by Aboriginal men in Queensland. Brisbane: Queensland Department of Corrective Services. 
36. Smallbone, S. W., \& Wortley, R. K. (2001). Child sexual abuse: Offender characteristics and modus operandi (Vol. 193). Australian Institute of Criminology.

37. Sullivan, J., \& Beech, A. (2004). A comparative study of demographic data relating to intra-and extra-familial child sexual abusers and professional perpetrators. Journal of Sexual Aggression, 10(1), 39-50.

38. Tunnell, K. (2002). The impulsiveness and routinization of decisionmaking. In A.R. Piquero and S.G. Tibbetts (eds.), Rational choice and criminal behavior: Recent research and future challenges. NY: Routledge.

39. Williams, F. P., \& McShane, M. D. (2004). Criminological theory. NY: Prentice Hall.

40. Wortley, R., \& Smallbone, S. (2006). Situational prevention of child sexual abuse. Crime prevention studies (Vol. 19). Monsey, NY: Criminal Justice Press.

41. Wortley, R. (2001). A classification of techniques for controlling situational precipitators of crime. Security Journal, 14(4), 63-82.

\title{
SITUACIONA PREVENCIJA SEKSUALNE ZLOUPOTREBE DECE
}

\author{
Zoran Pavlović ${ }^{62}$ \\ Univerzitet Privredna akademija u Novom Sadu, Pravni fakultet \\ Joris Bijvoets ${ }^{63}$ \\ Justitia Digitalis, Middenbeemster
}

Sažetak: Situaciona prevencija seksualne zloupotrebe dece predstavlja realitvno novi pristup u sprečavanju ove vrste viktimizacije najmlađih. Sumiranjem etioloških saznanja koja se tiču opšteg kriminaliteta i poznavanja riziko faktora seksualne viktimizacije formiran je sveobuhvatni pristup koji podrazumeva envajaromentalnu manipulaciju i jačanje protektivnih činilaca u predmetnom kontekstu. Prihvatajući značaj situacione prevencije u radu će biti predstavljene implikacije pojedinih fenomenoloških pokazatelja, analiza principa situacione prevencije, te pregled tipologije seksualnih delinkvenata i rizičnih faktora razvoja seksualne viktimizacije.

Ključne reči: zloupotreba dece, situaciona prevencija, faktori rizka, tipologija.

62 Zoran Pavlović, vanredni profesor i šef krivičnopravne katedre, zoran.pav@hotmail.com 63 Joris Bijvoets, privatni istražitelj, CEO Justitia Digitalis, Holandija. 